\title{
ELECTROCHEMICAL GENERATION OF USEFUL CHEMICAL SPECIES FROM LUNAR MATERIALS
}

\author{
Anthony F. Sammells and Krystyna W. Semkow \\ Eltron Research, Inc. \\ Aurora, Illinois 60504
}

\begin{abstract}
This work is directed towards the electrochemical characterization of a high temperature electrolytic cell which simultaneously generates oxygen at the anode and liquid alkali metals at the cathode. The electrolytic technology being investigated utilizes the oxygen vacancy conducting solid electrolyte, yttria-stabilized zirconia, which effectively separates the oxygen evolving (at $\mathrm{La}_{0.89} \mathrm{Sr}_{0.10} \mathrm{MnO}_{3}$ ) and alkali metal ( $\mathrm{Li}, \mathrm{Na}$ ) reducing (from a molten salt at either $\mathrm{Pt}$ or $\mathrm{FeSi}_{2}$ ) half-cell reactions. In the finally engineered cell liquid alkali metal would be continuously removed from the cathode compartment and used as an effective reductant for the direct thermochemical refining of lunar ores to their metallic state with simultaneous oxidation of the alkali metal to its oxide. The alkali metal oxide would then be reintroduced into the electrolytic cell to complete the overall system cycle.
\end{abstract}

\section{RESULTS AND DISCUSSION}

There are clear incentives to identify new technical strategies for the generation of useful chemical species from lunar materials directly on the Moon's surface. This is a consequence of the obvious high costs associated with the transportation of necessary materials from the Earth. The eventual development of a permanent manned base on the Moon's surface leading to eventual colonization by people will require a plentiful supply of both oxygen for breathing and refined metals for the assembly of permanent structures. In order to accomplish this, technologies must be characterized now for the extraction of oxygen from lunar ores and for their reduction to metal species by appropriately identified reducing agents, which might themselves be regenerated under lunar conditions.

Analysis of lunar soils and rocks collected during the highly successful Apollo program have shown conclusively the presence of pyroxene type minerals (iron magnesium calcium silicates), plagioclase feldspars (calcium aluminum silicates) and ilmenite (iron titanium oxides). Additionally, the presence of iron-nickel alloys was found, presumably of meteoric origin ${ }^{1,2}$. Thus, the major elements contained in such lunar "ores," from the random samples returned to Earth during the Apollo program, would appear to be oxygen, silicon, aluminum, calcium, iron, magnesium, titanium and nickel. Previous workers have suggested that oxygen might be extracted from ilmenite $\left(\mathrm{FeTiO}_{3}\right)$ via its initial chemical reduction by hydrogen initially transported from the Earth ${ }^{3-5}$. Other strategies suggested for the reduction of lunar metal ores 6,7 have included carbothermic reduction to give the desired metal species. 
Initial work on the high temperature electrochemistry of simulated lunar materials was performed on a number of metal silicate melts using platinum electrodes. Electrolysis of such melts has been shown to result in the simultaneous evolution of oxygen at the anode $8-12$ and the deposition of a reduced metal silicon alloy slag at the cathode $13-16$. This preliminary work by others clearly demonstrated the feasibility of high temperature molten salt electrochemical techniques as a strategy for the simultaneous generation of oxygen and reduced metal species from lunar type materials. The following technical limitations have however presented themselves in the direct electrorefining of molten salt lunar materials:

- Oxygen generated at the anode of a molten silicate electrolytic cell ( $\mathrm{CaMgSi}_{2} \mathrm{O}_{6}$ containing $\mathrm{Fe}^{3+}, \mathrm{Co}^{2+}$ or $\mathrm{Ni}^{2+}$ ) can become partly trapped within the electrolyte, creating a localized foam in the proximity of the anode. This can create problems associated both with the efficient removal of oxygen from the cell and in making such oxygen more susceptible to its electrochemical reduction at the cathode.

- Molten salt cells operated at temperatures ( $>1300^{\circ} \mathrm{C}$ ) where many chemical and electrochemical materials problems would be introduced limiting overall lifetime.

- Reduced metal or metal silicate species deposited at the cathode of high temperature molten silicate electrolyte cells will be dendritic in nature and will eventually lead to inter-electrode shorting. This is a common problem in both ambient and high temperature electrolytic cells where metals are deposited. No electrochemical technique or strategy has as yet been identified to satisfactorily address this issue for metal deposition.

- The continuous removal of reduced solid metallic species from the cathode would not be practical in such a cell and would consequently be limited to a batch type operation.

Many of the limitations implied by the above comments are currently being addressed by a program directed towards the development of an electrolytic cell which anodically evolves oxygen via an oxygen vacancy conducting solid electrolyte and simultaneously deposits a liquid alkali metal at the cathode. Liquid sodium or lithium deposited at the cathode could be continually removed in the finally engineered cell and used as a valuable reducing agent for the refining of lunar 'ores' via for example the general chemical reaction:

$$
2 \mathrm{Li}(\text { or } \mathrm{Na})+\mathrm{MO} \rightarrow \mathrm{Li}_{2} \mathrm{O}+\mathrm{M}
$$

where MO is a metal oxide ore on the lunar surface. The overall electrolytic cell being developed possesses the general configuration:

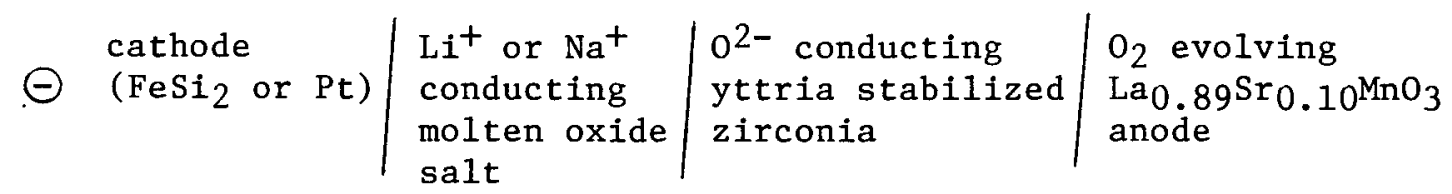

The anodic reaction in this cell corresponds to

$$
\mathrm{O}^{2-} \rightarrow \frac{1}{2} \mathrm{O}_{2}+2 \mathrm{e}
$$

with the cathodic reaction being

$$
2 \mathrm{Li}^{+}(\mathrm{Na})+2 \mathrm{e} \rightarrow 2 \mathrm{Li}(\mathrm{Na})
$$


giving the overall reaction

$$
\mathrm{Li}_{2} \mathrm{O}\left(\mathrm{Na}_{2} \mathrm{O}\right) \rightarrow 2 \mathrm{Li}(\mathrm{Na})+\frac{1}{2} \mathrm{O}_{2}
$$

A schematic of the experimental arrangement being developed is shown in Figure 1. Molten salts being evaluated for incorporation into the cathode compartment of this cell include $\mathrm{Li}_{2} \mathrm{O}(24 \mathrm{~m} / \mathrm{o})-\mathrm{Na}_{2} \mathrm{O}, \mathrm{Li}_{2} \mathrm{O}(66 \mathrm{~m} / \mathrm{o}) \mathrm{B}_{2} \mathrm{O}_{3}$, and $\mathrm{Li}{ }_{2} \mathrm{O}-\mathrm{LiF}-\mathrm{LiCl}$. As can be seen from Figure 1, containment of the alkali oxide containing molten salts is being accomplished by the use of zirconia based solid electrolytes stabilized in the cubic form by the introduction of lower valence metal ions. This introduces oxygen vacancies necessary to produce $0^{2-}$ conductivity at high temperature. Materials which have frequently $17-23$ been introduced to promote such conductivity have included $\mathrm{CaO}, \mathrm{Ce}_{2} \mathrm{O}_{3}, \mathrm{Y}_{2} \mathrm{O}_{3}$ and $\mathrm{Yb}_{2} \mathrm{O}_{3}$. By comparing the oxygen ion vacancy conductivity of the various stabilized zirconias at around $900^{\circ} \mathrm{C}$, it appears that highest conductivities (by a factor of 5-10) are realized for the rare earth stabilized materials, compared to those containing calcia. Previous workers 24 have shown that yttria-stabilized zirconia also possesses some resistance to corrosion in high temperature silicate melts. Thus, the presence of trace silicates in alkali metal oxide electrolysis cell should not be a major technical iimitation.

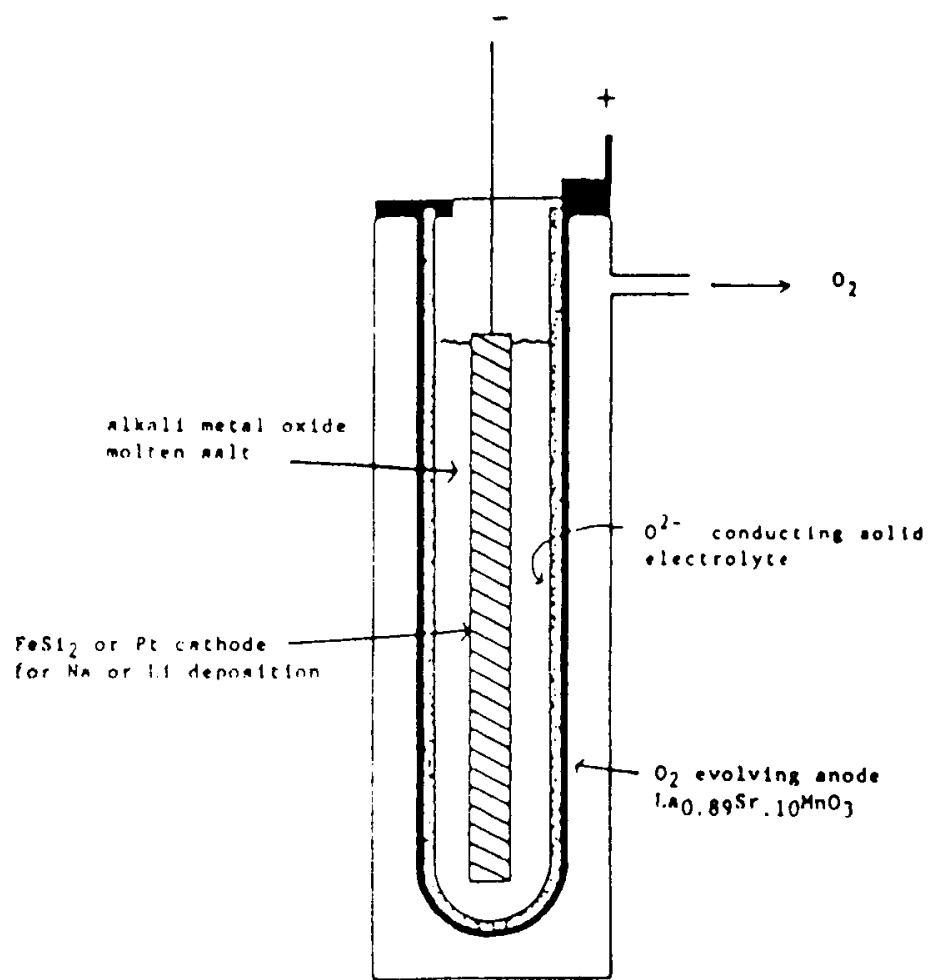

Figure 1. Schematic drawing of yttria stabilized zirconia cell being developed for the electrolytic generation of alkali metals and oxygen from molten alkali metal oxide melts.

Investigation of $(24 \mathrm{~m} / \mathrm{o}) \mathrm{Li}_{2} \mathrm{O}-\mathrm{Na}_{2} \mathrm{O}$ molten oxides at $800^{\circ} \mathrm{C}$ in a stainless steel container using platinum working and counter electrodes, gave a polarization curve suggesting electrolysis of the melt to form oxygen and alkali metal. Sodium was observed in the cell after its disassembly. This in part could be promoted by the direct thermal decomposition of sodium oxide to sodium at the temperatures used. 
Other investigations were directed towards electrolysis of $\mathrm{Li}_{2} \mathrm{O}$ in $\mathrm{LiCl}$ $(70 \mathrm{~m} / \mathrm{o})-\mathrm{LiF}$ melts. The liquidus curve for this ternary melt is shown in Figure 2. Melting points were determined using DC resistance measurements. Ionic conductivity for $\mathrm{Li}_{2} \mathrm{O}(5-28 \mathrm{~m} / \mathrm{o})$ in $\mathrm{LiCl}(70 \mathrm{~m} / \mathrm{o})-\mathrm{LiF}$ were found to be in the range $2-40 \mathrm{hm}^{-1} \mathrm{~cm}^{-1}$ at $600-700^{\circ} \mathrm{C}$ as determined using $\mathrm{AC}$ impedance measurements. A current overpotential curve for the cell

$$
\mathrm{FeSi}_{2}\left|\begin{array}{c}
(23.9-23.6-52.5) \mathrm{m} / \mathrm{o} \\
\mathrm{Li}{ }_{2} \mathrm{O}-\mathrm{LiF}-\mathrm{LiC} 1
\end{array}\right| \mathrm{ZrO}_{2}\left(8 \mathrm{w} / \mathrm{o} \mathrm{Y}_{2} \mathrm{O}_{3}\right)\left|\mathrm{La}_{0.89} \mathrm{Sr}_{0.10} \mathrm{MnO}_{3}\right| \mathrm{Pt}
$$

is shown in Figure 3. The cell had an initial open-circuit voltage of $1.43 \mathrm{~V}$ at $700^{\circ} \mathrm{C}$ and gave current densities at the $\mathrm{FeSi}_{2}$ electrode of $60 \mathrm{~mA} / \mathrm{cm}^{2}$ at $1.0 \mathrm{~V}$ applied overpotential. Lithium deposition was observed to proceed via the formation of a series of progressively more negative $\mathrm{Li}_{\mathrm{x}} \mathrm{FeSi} \mathrm{i}_{2}$ voltage plateaus. 0xygen evolution from the anode was found to be Faradaic. The temperature dependency for cell resistance is shown in Figure 4. The activation energy obtained from the slope $(23.2 \mathrm{kcal} / \mathrm{mole})$ agrees well with the activation energy for oxide ion diffusion through calcia stabilized zirconia 25 . Thus, the overall cell resistance is predominantly due to the solid electrolyte. Thus, zirconia solid electrolyte geometry will be of importance in the finally engineered cell. Also, appropriate provision will be necessary for both the convenient removal of liquid lithium from the cathode compartment and for the reintroduction of $\mathrm{Li}_{2} \mathrm{O}$ into the molten salt electrolyte.

The electrochemical results briefly outlined above clearly show the technical viability of this overall strategy for the indirect electrochemical refining of lunar ores to produce reduced metals and oxygen.

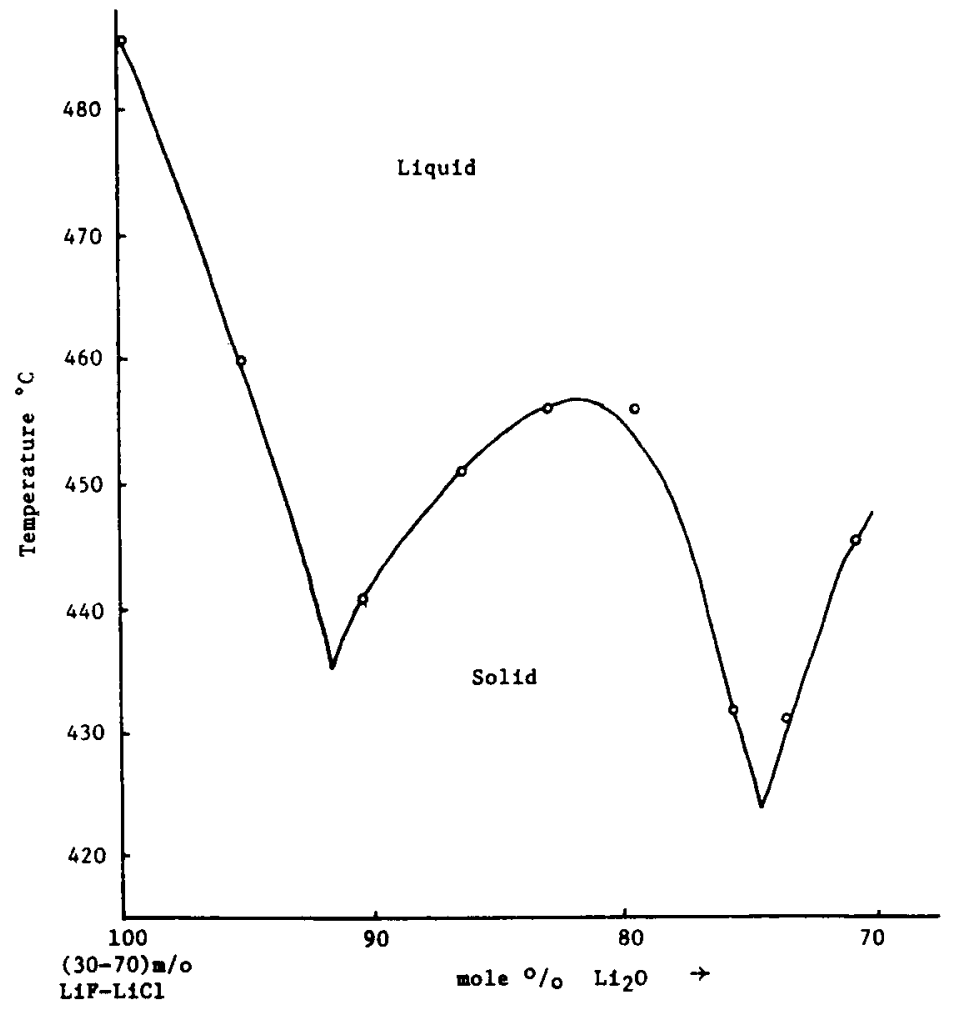

Figure 2. Liquidus curve for the system $\mathrm{Li}_{2} \mathrm{O}-(30 \mathrm{~m} / \mathrm{o} \mathrm{LiF}, 70 \mathrm{~m} / \mathrm{o} \mathrm{LiCl})$. 


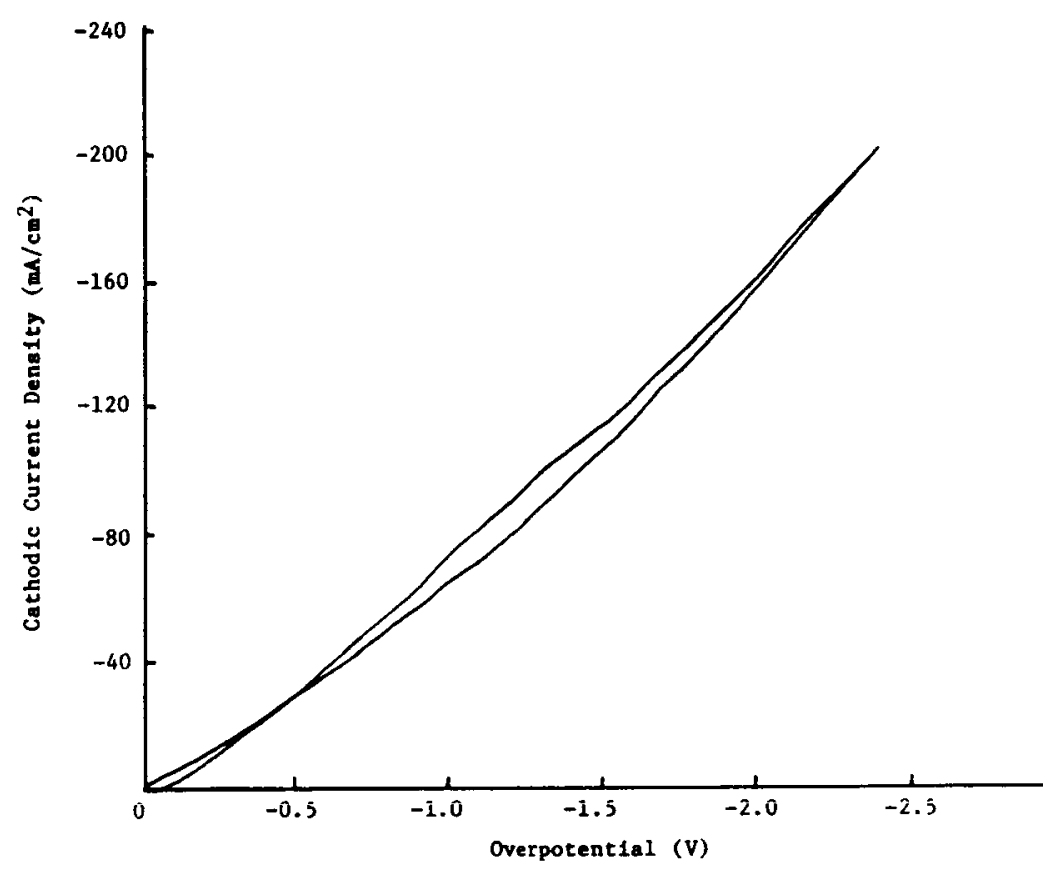

Figure 3. Current-overpotential curve for the cell $\mathrm{FeSi}_{2} / \mathrm{Li}_{2} \mathrm{O}(23.9 \mathrm{~m} / \mathrm{o})-$ $\mathrm{LiF}(23.6 \mathrm{~m} / \mathrm{o})-\mathrm{LiCl}(52.5 \mathrm{~m} / \mathrm{o}) / \mathrm{ZrO}_{2}\left(8 \mathrm{w} / \mathrm{o} \mathrm{Y}_{2} \mathrm{O}_{3}\right) / \mathrm{La}_{0} .89 \mathrm{Sr}_{0} .10 \mathrm{MnO}_{3} / \mathrm{Pt}$. Open-circuit voltage $1.43 \mathrm{~V}$. Temperature $700^{\circ} \mathrm{C}$. Voltage scan rate $0.1 \mathrm{~V} / \mathrm{sec}$.

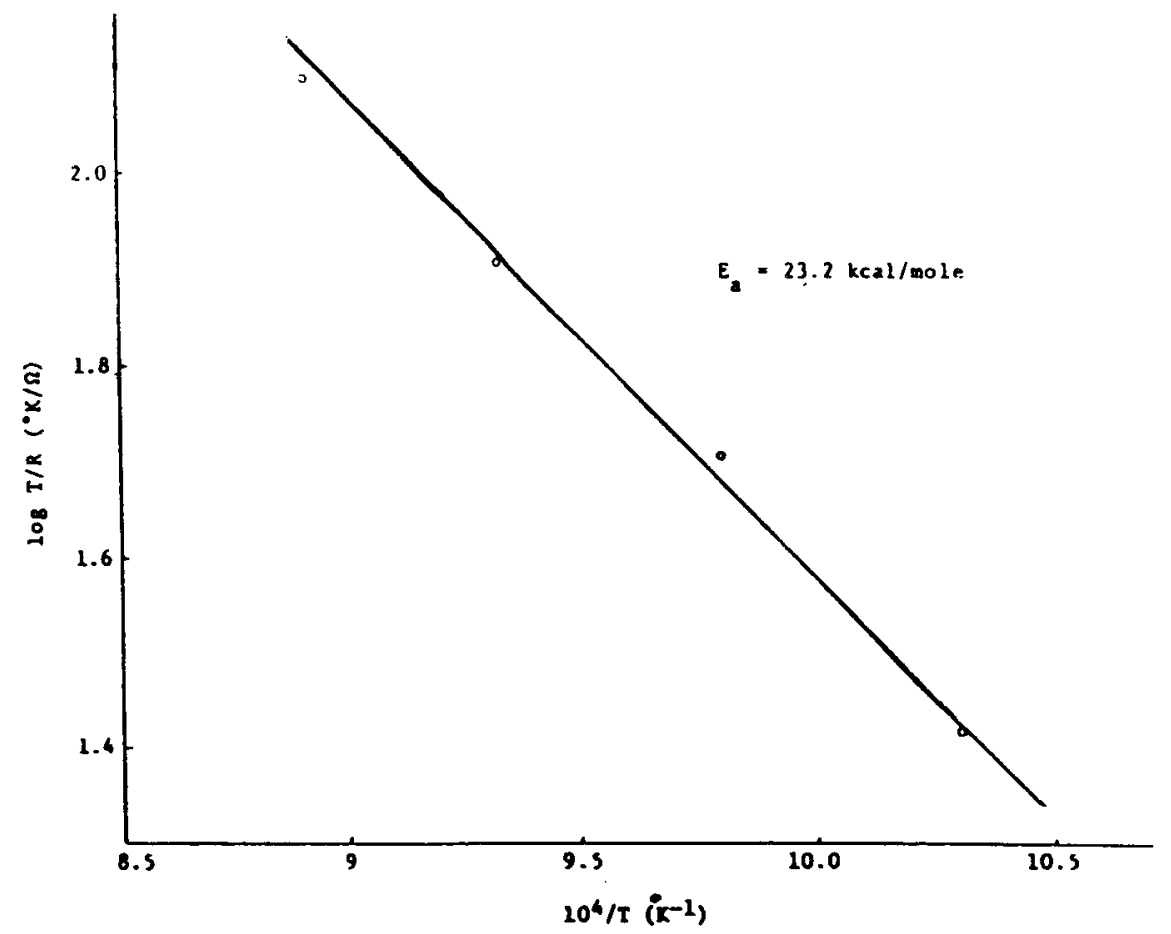

Figure 4. Temperature dependence for the resistance of the cell $\mathrm{Pt} /$ $\mathrm{La}_{0.89} \mathrm{Sr}_{0.10} \mathrm{MnO}_{3} / \mathrm{ZrO}_{2}(5 \mathrm{w} / \mathrm{o} \mathrm{CaO}) / \mathrm{Li}_{2} \mathrm{O}(5 \mathrm{~m} / \mathrm{o})-\mathrm{LiF}(28.5 \mathrm{~m} / \mathrm{o})-$ $\operatorname{LiCi}(66.5 \mathrm{~m} / \mathrm{o}) / \mathrm{Fe}$. 


\section{REFERENCES}

1. R. D. Waldron and D. R. Criswe11, Princeton Conf. on Space Manufacturing Facilities, Report 79-1379, Princeton, New Jersey, (1979).

2. R. J. Williams and J. J. Jadwick, Handbook of Lunar Materia1s, NASA, 1980.

3. H. P. Davies, Eagle Engin. Report 非EL 83-63, Houston, (1983).

4. M. A. Gibson and C. W. Knudsen in Lunar Bases and Space Activities of the 21st Century, NASA, 1984 , p. 26.

5. E. Kibler, L. W. Taylor and R. J. Williams in Lunar Bases and Space Activities of the 21st Century, NASA, 1984, p. 25 .

6. W. C. Phinney, et. al., in Space Based Manufacturing From Nonterrestrial Materials, Amer. Inst. of Aeronautics and Astronautics, New York, 1977.

7. A. H. Cutler in Lunar Bases and Space Activities of the 21st Century, NASA, 1984, p. 22.

8. K. W. Semkow and L. A. Haskin, Geochim. Cosmochim. Acta, 49, 1897 (1985).

9. K. W. Semkow and L. A. Haskin, Abstracts to Lunar Plant Sci., XVI, 1985, p. 761 .

10. A. Ghosh and T. B. King, Trans. Meta11. Soc., AIME, 245, 145 (1969).

11. J. K. Higgins, Glass Technol., 23, 90 (1982).

12. J. K. Higgins, Glass Techno1., 23, 180 (1982).

13. D. S. Kesterke, U.S. Dept. of Interior Bureau of Mines Report of Invest. RI-7587, (1971).

14. D. J. Lindstrom and L. A. Haskin in Space Manufacturing Faciltiies 3, T. Grey and C. Krop, Eds., Amer. Inst. Aeronautics and Astronautics, New York, 1979.

15. W. F. Carrol1, Jet Propulsion Laboratory Report 83-36, (1983).

16. R. H. Lewis, D. J. Lindstrom and L. A. Haskin, Abstracts to Lunar Planet Sci., XVI, 1985, p. 489.

17. H. S. Spacil and C. S. Tedmon, Jr., J. Electrochem. Soc., 116, 1627 (1969).

18. W. Fisher, H. Kleinschmager, F. J. Rohr, R. Steiner and H. H. Eysel, Chem. Ing. Tech., 44, 726 (1972).

19. R. Bohm and H. Kleinschmager, Z. Naturforsch, 269, 780 (1971).

20. R. Steiner, Energ. Conv., 12, 31 (1972).

21. H. L. Tuller and A. S. Nowick, J. Electrochem. Soc., 122, 255 (1975).

22. T. Kudo and H. Obayashi, J. Electrochem. Soc1, 122, 142 (1975).

23. T. H. Etse11 and S. N. Flengas, J. Electrochem. Soc., 118, 180 (1971).

24. T. Tran and M. P. Brungs, Phys. Chem. Glasses, 21, 133 (1980).

25. D. K. Hohnke in Fast Ion Transport in Solids, P. Vashishta, J. N. Mundy and G. K. Shenoy, Eds., North-Holland, New York, 1979, p. 669. 